\title{
PHYLOGEOGRAPHY OF EARTHWORMS FROM HIGH LATITUDES OF EURASIA
}

\author{
Sergei Victorovich Shekhovtsovi,2, ${ }^{1,}$, Danill Iosifovich Berman ${ }^{2}$ \\ Nina Antonovna Bulakhova ${ }^{2,3}$, Olga Lvovna Makarova ${ }^{4}$ \\ and Sergei Evgenievich Peltek ${ }^{1}$ \\ ${ }^{1}$ Institute of Cytology and Genetics SB Russian Academy of Sciences \\ Pr. Lavrentieva 10,630090 Novosibirsk, Russia; E-mail: shekhovtsov@bionet.nsc.ru \\ ${ }^{2}$ Institute of Biological Problems of the North \\ Portovaya St. 18,685000 Magadan, Russia; E-mail: dberman@mail.ru \\ ${ }^{3}$ Tomsk State University, Prospekt Lenina 36, 634050 Tomsk, Russia; E-mail: sigma44@mail.ru \\ ${ }^{4}$ Severtsov Institute of Ecology and Evolution \\ Leninskij prosp. 33, 119071 Moscow, Russia; E-mail:ol_makarova@mail.ru
}

Earthworms are an important component of soil fauna even in high latitudes, in the taiga and tundra biomes. It is yet unclear if earthworm populations from these regions are autochtonous or recent invaders. We collected earthworms from approximately from $64^{\circ}$ to $73^{\circ} \mathrm{N}$ from the Kola Peninsula to Chukotka and genotyped it using the COI gene. We found Dendrobaena octaedra, Lumbricus rubellus, and Eisenia nordenskioldi nordenskioldi. Within E. n. nordenskioldi, two cryptic phylogenetic lineages were detected, namely lineages 1 and 9 that were characterized in our previous studies. The western part (from the Kola Peninsula to the Taimyr Peninsula) contained D. octaedra, L. rubellus and both lineages of E. n. nordenskioldi; their COI sequences were closely related to those from very remote (up to several thousand $\mathrm{km}$ ) populations. On the contrary, in the east (from the basins of the Anabar River to the Chukotka Peninsula) we found solely E. n. nordenskioldi belonging mostly to lineage 9 and its haplotype groups from various parts of this region differed significantly, indicating long-term divergence. Thus, our data suggests that earthworms recolonized northwestern Eurasia in the Holocene, while the climate in its eastern part was sufficient for earthworm survival even during glaciation maximums.

Key words: earthworms, Lumbricidae, DNA barcoding, tundra, taiga.

\section{INTRODUCTION}

Although earthworms are rather delicate creatures, they are still able to survive in cold and dry climates (Meshcheryakova \& Berman 2014). Naturally, they are usually smaller in size and not as numerous in extreme environments as in the much more favorable soil conditions of the temperate zone: in tundra and in acidic taiga soils there are about 2-4 individuals per $\mathrm{m}^{2}$ (Tiкномirov 1937, Stebaev 1959). However, in certain intrazonal habitats of these biomes, e.g., on southern slopes with meadow vegetation, earthworm density may be as much as 150 individuals per $\mathrm{m}^{2}$ (CHERNov 1965). 
Not all northern regions have equally favorable conditions for earthworms. Fennoscandia, which is heated by the Gulf Stream, harbors the highest earthworm diversity; a wide range of cosmopolitan species that live far to the south (Lumbricus rubellus Hoffmeiser, 1843, L. terrestris L., 1758, Aporrectodea caliginosa (Savigny, 1826), A. rosea (Savigny, 1826), Eiseniella tetraedra (Savigny, 1826), Dendrodrilus rubidus (Eisen, 1874), Dendrobaena octaedra (Savigny, 1826), Octolasion cyaneum (Savigny, 1826)) was found to the north of the 65 parallel (Haraldsen \& Engelstad 1998), and most of these species were detected as far as the northern coast of the Scandinavian Peninsula (Terhivuo 1988). On the Kola Peninsula, A. caliginosa, D. octaedra, D. rubidus, and L. rubellus were found beyond the Polar Circle (Zenkova et al. 2011, Rybalov \& Kamaev 2012). Similar earthworm fauna consisting of cosmopolitan species only was detected in Iceland and Greenland (a total of 15 species: BLAKEMORE 2007) and North America (approximately ten species from the 60th to the 64th parallels; no earthworms were found further to the north yet: BERMAN \& MARUSIK 1994, ReYNolds 1995, 2017).

Less is known about the north of Eurasia. In the tundra biome, the prevalent earthworm species is D. octaedra in Fennoscandia and the European Russia (Michaelsen 1903), and E. n. nordenskioldi in the Asian Russia (VsevolodovaPerel 1997); ranges of these species partly overlap. Eisenia atlavinyteae, a close relative of $E$. $n$. nordenskioldi, is found in the north of West Siberia and on the Taimyr Peninsula (Vsevolodova-Perel 1997, Striganova \& Porjadina 2005). For European tundra, besides the mentioned species, the cosmopolitan A. caliginosa, L. rubellus, and L. terrestris were also reported by several studies (Vsevolodova-Perel 1997, Konakova et al. 2017); however, we should note that to our opinion reports on the latter species are results of misidentification. On the whole, both faunistic records listed above and experimental research on cold tolerance (Meshcheryakova \& Berman 2014) suggest that several earthworms can survive beyond the Polar Circle. Although winter air temperatures are very low there, temperature fluctuations in soil are significantly milder.

In addition to harsh climate, soil fauna in the North was significantly affected by the Pleistocene glaciation cycles. It is generally believed that the north of Western Europe and North America were covered by glacial sheets that erased the majority of the fauna (Hewitr 2000), but some species could survive in nunataks (Provan \& Bennett 2000). The latter variant seems unlikely for earthworms, however, such hypotheses were proposed for Fennoscandia (Fridolin 1936, Stöp-Bowitz 1969) and Greenland (Hansen et al. 2006). Northeastern Eurasia, however, had only limited glaciation but harsher climate. Thus it is unclear if the earthworm populations currently inhabiting high latitudes survived glaciations in situ or colonized these regions only recently. On the one hand, many earthworm species found in the North, especially D. octaedra, are capable of rapid dispersal (JAmes 2011). On the other 
hand, certain studies (SheKhovtsov et al. 2015, 2018a) suggest that at least some earthworm population living beyond the Polar Circle could survive several Pleistocene glaciations in situ.

It is impossible to determine which of the aforementioned hypotheses is correct based on morphological data alone. However, molecular genetic data could reveal that, since earthworms are characterized by very high genetic diversity. Currently no such studies were performed, although populations of various species from more southern regions of Scandinavia do not show significant differences from those of Southern Europe (Martinsson \& ERsÉus 2017, MARTINSson $e$ t al. 2017). We collected a sample of earthworms from high latitudes of Eurasia (approximately from $64^{\circ}$ to $73^{\circ} \mathrm{N}$ ) from the Kola Peninsula to Chukotka and compared their COI mtDNA haplotypes to those from southern regions.

\section{MATERIAL AND METHODS}

Earthworm samples were collected in 2010-2016 in 30 locations from the Kola Peninsula to Chukotka (Table 1, Fig. 1) and fixed by ethanol. Morphological identification was performed according to Vsevolodova-PERel (1997). DNA was extracted from several caudal segments using BioSilica DNA extraction kits (Novosibirsk). A fragment of the COI gene was amplified in $20 \mu \mathrm{l}$ of mixture containing $60 \mathrm{mM}$ Tris- $\mathrm{HCl}, 1.5 \mathrm{mM} \mathrm{MgCl}, 25 \mathrm{mM}$ $\mathrm{KCl}, 10 \mathrm{mM}$ 2-mercaptoethanol, $0.1 \%$ Triton X-100, and $1 \mathrm{u}$ of TaqSE polymerase (SibEnzyme, Novosibirsk).

The COI fragment of $E$. $n$. nordenskioldi was amplified using universal primers LCO1490m (5'-TACTC-AACAA-ATCAC-AAAGA-TATTG-G-3'; modified from Folmer et al. 1994) and HCO2198 (5'-TAAAC-TTCAG-GGTGA-CCAAA-AAATC-A-3'; Folmer et al. 1994); for D. octaedra and L. rubellus we used LCO1490m and COI-E (5'-TATAC-TTCTGGGTGT-CCGAA-GAATC-A-3'; BELY \& WrAy 2004).

The GenBank database and our own barcoding collection were used for sequence identification. Haplotype networks were constructed using Network 5.0 (fluxus -engineering.com) with the Median Joining algorithm.

\section{RESULTS}

We obtained a total of $321 \mathrm{COI}$ sequences belonging to the following species: D. octaedra, L. rubellus, and E. n. nordenskioldi (Table 1); all were 658 bp in length and contained no indels.

Lumbricus rubellus $(\mathrm{n}=24)$ was detected only in the two westernmost locations (no. 1 and 2) in Karelia and the Archangelsk oblast. Six haplotypes were found in 24 studied individuals, all of them belonged to lineage 2 of this species that was earlier found in Western Europe and North America (King et al. 2008, Martinsson et al. 2018). They differed by up to nine substitutions from the most closely related GenBank entries, i.e. from Great Britain (LT900525), New Zealand (KX790515), USA (JQ909121, JQ909117), and Canada (JQ909105). 


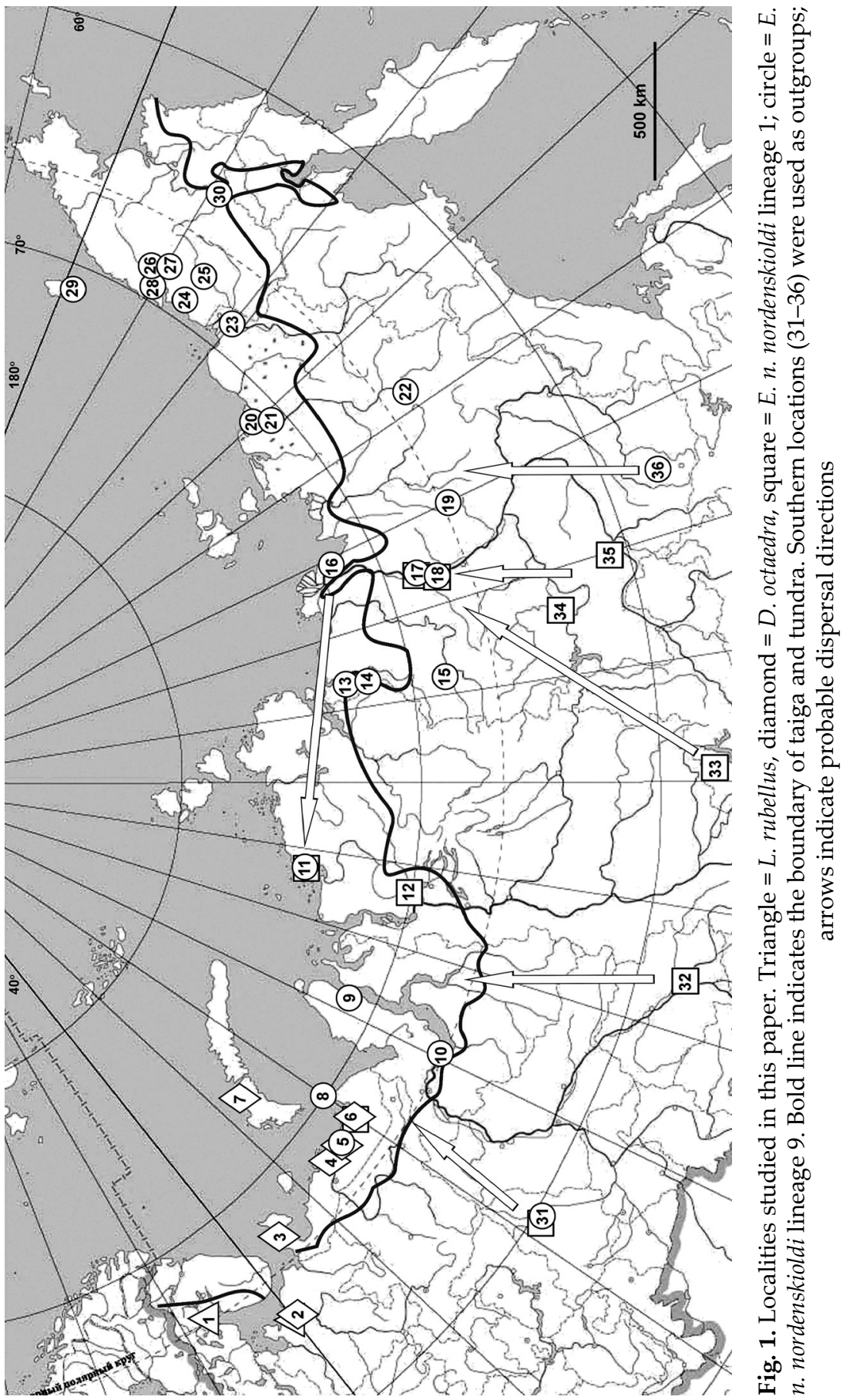




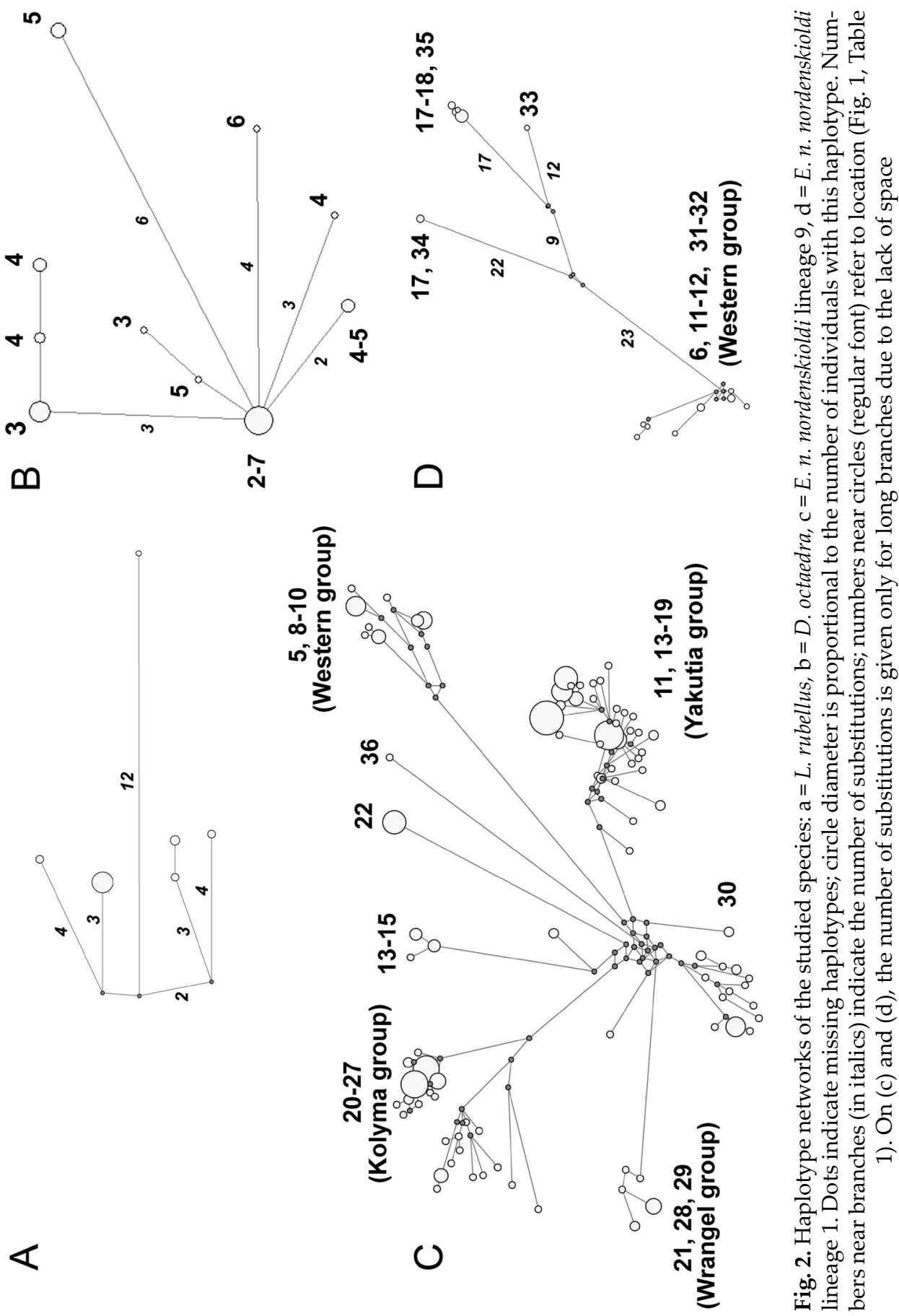




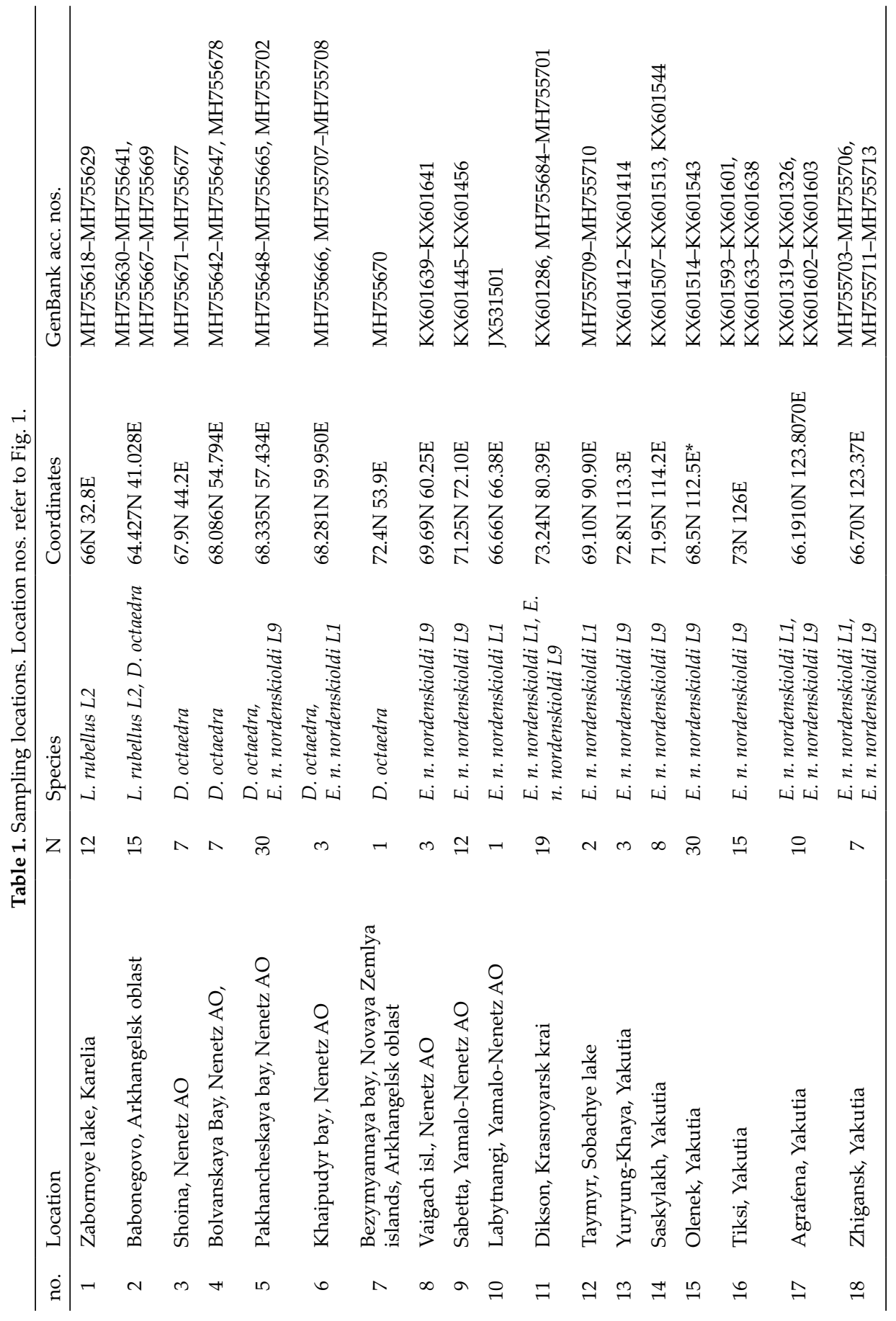




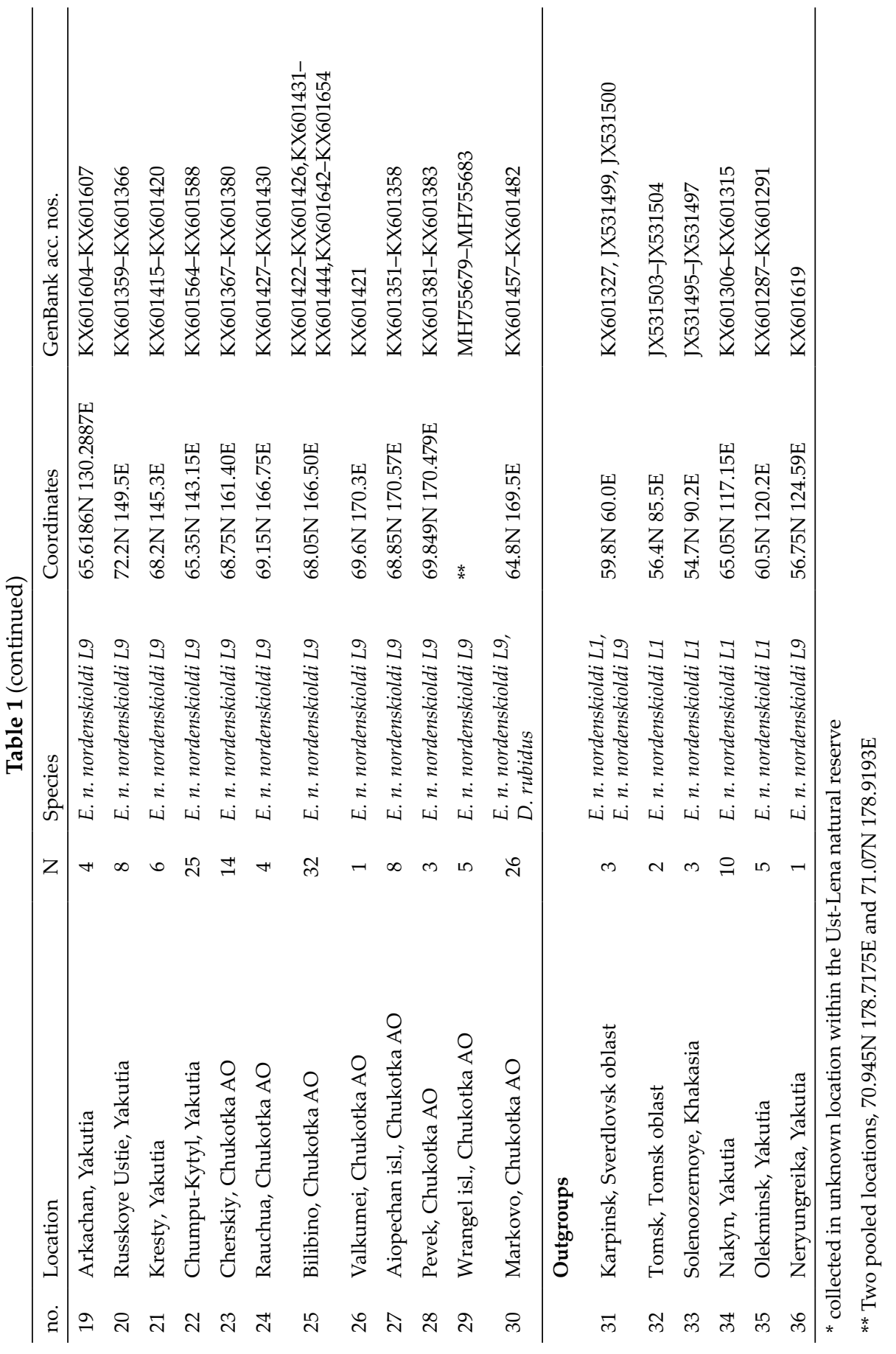


Dendrobaena octaedra $(\mathrm{n}=37)$ was found in six locations (nos. 2-7) from the Arkhangelsk oblast to the coast of the Pechora Sea, as well as on the Southern Island of Novaya Zemlya. We detected eleven haplotypes of this species that were also found in other parts of the worlds. The most widespread haplotype that was present in about a third of individuals was identical to a GenBank accession from Denmark (FJ214235) and differed by one nucleotide substitution from specimens from Austria (DQ092896) and North America (KU496868, KM611907, JQ909028, JQ909013).

Our sample of Eisenia $n$. nordenskioldi was represented by two genetic lineages, $1(\mathrm{n}=17)$ and $9(\mathrm{n}=243)$ (see Shekhovtsov et al. 2013, 2018a). Sequences of lineage 1 could be divided into two groups (Fig. $2 d$ ), one from the west (Nenetz Autonomous okrug and the north of the Krasnoyarsk krai (Nenets Autonomous Okrug and the north of the Krasnoyarsk oblast; locations 6, 11,12 ), and two from the east (middle reaches of the Lena River; locations 17-18). Worms belonging to the second eastern groups were found only on the Agrafena island (location 17). It is noteworthy that each group has close relatives in more southern regions: the sequences of the western group are very similar to those from the Middle Urals and Tomsk (locations 31 and 32) that were found in our previous studies (SHEKHOvTsov et al. 2013); whereas sequences of the eastern group are close to those from Khakassia Republic and the Olekminsk town (northwestern Yakutia) (Figs 1, 2d).

The 9th lineage of E. n. nordenskioldi had the highest genetic diversity. In part it may be explained by larger sample size. However, it demonstrated the most pronounced phylogeographic patterns (Fig. 2c). We detected several geographically restricted clusters, i.e., the western groups (from the Nenets Autonomous okrug and Yamalo-Nenets autonomous okrug; locations 5, 8-10); the Olenek group (locations 13-15) with the haplotypes restricted to the basins of Olenek River and Anabar River; the Yakutia group (locations 11, 13-19) that encompassed locations throughout Yakutia; the Kolyma group (locations 20-27) that also included populations from the East Siberian Sea shore; and the Wrangel group (locations 21, 28, 29) with populations from the Wrangel island and the coast of the East Siberian Sea. Several minor branches were detected as well (Fig. 2c). Boundaries between the observed groups were not strict, and highly diverged haplotypes could be found within a single location.

\section{DISCUSSION}

Intraspecific diversity

Among our northern samples, L. rubellus was found only in the two westernmost locations ( 1 and 2). Cold tolerance of this species is low (MesHCHERYAKOVA \& BERMAN 2014), and its northern records are mostly associated 
with human settlements and fishing sites (Tiunov et al. 2006) that suggests that it was introduced there recently. Our genetic data corroborate this viewpoint, as the haplotypes from the studied locations were closely related to those from the West European populations.

Dendrobaena octaedra COI haplotypes from various regions of the world are closely related, and no cryptic phylogenetic lineages can be discerned, as opposed to the majority of cosmopolitan species, e.g. L. rubellus (Martinsson \& Erséus 2017), A. rosea (King et al. 2008), A. longa (Ude, 1826) (Martinsson et al. 2017), and A. caliginosa (SheKHovtsov et al. 2016c). Judging by GenBank entries, $D$. octaedra contains significant intraspecific diversity, but does not demonstrate any geographical patterns: North European populations were found to be very similar to other European ones (CAMERON et al. 2008). This is true for Asian populations of this species as well (SHeкHovtsov et al. 2014, 2018b). Individuals sampled by us were also identical or closely related to those from West Europe and America, which indicates recent colonization, as in the case of L. rubellus. It is noteworthy that COI of D. octaedra from Novaya Zemlya (location 7) was also very close to West European haplotypes. The Kara Strait is deeper than $100 \mathrm{~m}$, so the archipelago obviously was not connected to the mainland during Pleistocene glaciations. Therefore, D. octaedra was most likely introduced to Novaya Zemlya only recently.

However, in contrast to L. rubellus, cold tolerance of D. octaedra is high both on the adult and cocoon stages (BERMAN et al. 2002), so existence of other lineages that survived Pleistocene glaciations in the north and were not yet detected is quite possible. So, Hansen et al. (2006) suggested that for D. octaedra from Greenland, which seems to be genetically distant from European and American populations. Unfortunately, this study was performed using allozymes, and its results thus cannot be directly compared with DNA data.

Eisenia nordenskioldi nordenskioldi, like many other earthworm species, was found to contain at least nine genetic lineages that have different distribution patterns and are sometimes associated with different physiographic regions (SHEKHOvTsov et al. 2013, 2016a,b). Each of the lineages is also characterized by significant diversity with deep phylogeographic patterns.

Haplotypes of E. n. nordenskioldi lineage 1 from our sample belonging to the western group were closely related to each other (differed by only 1-2 substitutions), as well as to those from the Middle Urals (location 31) and West Siberia (location 32). This suggests their recent dispersal, most probably during the Holocene. It would be reasonable to suggest that earthworms dispersed from the south to the north, and not vice versa, probably along the course of the $\mathrm{Ob}^{\prime}$ River. It is impossible to hypothesize anything about eastern haplotypes of lineage 1 yet, because very few locations were sampled.

The situation with E. n. nordenskioldi lineage 9 is more complicated. We do not know where the ancestral range of this lineage may be, but phylogeo- 
graphic analysis indicates that populations forming the basal branches on its tree reside the southern Yakutia (location 36) (SHeKHovtsov et al. 2018a) suggesting that the ancestral range might be in more southern regions. In Northeastern Asia (Yakutia and Chukotka), populations of lineage 9 demonstrate high level of differences among geographic regions (Fig. 2c). Certain clusters are found exclusively in the northernmost locations. Judging by the significant number of substitutions, one can consider that their dispersal occurred long before the LGM.

For example, haplotypes of the Wrangel group (locations 21, 28, 29) differ from those of the Kolyma group (locations 20-27) by about as many substitutions as the western and eastern groups of $E$. $n$. nordenskioldi lineage 1. This implies that clusters of lineage 9 from the high latitudes survived at least several glaciation cycles (SHEKHOvTsov et al. 2018a).

In the west, from the coast of the Barents Sea to Taimyr (locations 5, 8-11), phylogeographic patterns are dramatically different. Haplotypes from locations 5 and 8-10 are all very closely related to that from location 31 that is far to the south (Fig. 1), and those from Taimyr (location 11) appeared to be very similar to the Yakutia group. Similarly to D. octaedra and E. n. nordenskioldi lineage 1 from the same regions, we can hypothesize that northern populations of lineage 9 dispersed here from the south and east, respectively.

\section{Global patterns of earthworm distribution in the northern Eurasia}

Patterns of current earthworm dispersal in the North were influenced by paleogeographic events. It is well known that during the LGM a big part of northern Europe was covered by a solid ice sheet (SvENDSEN et al. 2004). Although Northern Asia had colder climate, precipitation was low, which is why this region underwent only scattered mountain glaciation. The Urals, as well its northern enclave, Novaya Zemlya, was undoubtedly either covered by glaciers (SVENDSEN et al. 2004) or had strongly changed environments (MANGerud et al. 2008). Thus it is reasonable to assume that locations 1 to 8 of our sample are from the territories whose soil fauna was altered or "erased" during the LGM.

The observed patterns of earthworm distribution were in accordance with this viewpoint. Northern territories west of the Urals were populated by cosmopolitan species of European origin. In Northern Europe, climate gets harsher toward the east and only the most resistant species remain. D. octaedra had the largest distribution among North European invaders because of its high propensity to dispersal (partly caused by small size and obligate parthenogenesis) and high cold tolerance (up to $-16^{\circ} \mathrm{C}$; BERMAN et al. 2002). 
Although Northeast Asia had extremely harsh climate during glaciation periods, the sufficient conditions for earthworm survival seem to have maintained, and E. n. nordenskioldi was ubiquitous here (we failed to detect E. atlavyniteae in our sample).

Genetic data obtained in this study is in agreement with the abovementioned data. Our sample can be divided in two parts, western (locations 1-12) and eastern (locations 13-30) ones. The western set contains several species that are similar in that all of them have haplotypes very close $(98-100 \%$ sequence similarity) to those from populations sampled in thousands kilometers from them, i.e., in West Europe (D. octaedra and L. rubellus) or southwestern Siberia (E.n. nordenskioldi lineage 1). Populations of E. n. nordenskioldi lineage 9 from locations 5, 6, and 9 are very close to that from location 31 from Middle Urals (Fig. 1), while that from the Taimyr, are resembling haplotypes from Yakutia (locations 16-19). It is reasonable to suggest that such dispersal patterns reflect recent, most probably Holocene dispersal.

The eastern part of our sample was mostly represented by lineage 9 of E. n. nordenskioldi. The observed patterns were geographically structured and contained significant genetic differences among population groups, indicating that they diverged long ago, at least before the LGM.

The obtained molecular data are in good accordance with the conventional paleogeographic data, that suggest that northern Europe biota suffered strong disturbance during glaciation maximums, while northern Asia had only limited glaciation and environmental changes.

Acknowledgements - This study was supported by the Russian Fund for Basic Research (grants 18-04-00507_a and 16-04-00082_a) and the State Assignment № 0324-20180017. We are grateful to N. E. Bazarova for technical assistance, and to all colleagues that took part in the collection of material, i.e., S. Kharitonov, A. Babenko, A. Makhrov, V. Spitsyn, M. Bizin, A. Tanasevitch, and Z. Yanchenko.

\section{REFERENCES}

Bely, A. E. \& Wray, G. A. (2004): Molecular phylogeny of naidid worms (Annelida: Clitellata) based on cytochrome oxidase I. - Molecular Phylogenetics and Evolution 30: 50-63. https://doi.org/10.1016/S1055-7903(03)00180-5

Berman, D. I. \& Marusik, Y. M. (1994): On Bimastos parvus (Oligochaeta: Lumbricidae) from Yukon Territory (Canada), with discussion of distribution of the earthworms in northwestern North America and northeastern Siberia. - Megadrilogica 5: 113-116.

Berman, D. I., Meshcheryakova, E. N., Alfimov, A. V. \& Leyrikh, A. N. (2002): The distribution of the earthworm Dendrobaena octaedra (Lumbricidae: Oligochaeta) in 
northern Holarctics is limited by insufficient cold tolerance. - Zoological Zhurnal 81: $1210-1221$.

Blakemore, R. J. (2007): Checklist of megadrile earthworms from Greenland and Iceland. http:// www.annelida.net/earthworm/Greenland\%20and\%20Iceland\%20earthworms.pdf

Cameron, E. K., Bayne, E. M. \& Coltman, D. W. (2008): Genetic structure of invasive earthworms Dendrobaena octaedra in the boreal forest of Alberta: insights into introduction mechanisms. - Molecular Ecology 17: 1189-1197. https://doi.org/10.1111/j.1365 $-294 X .2007 .03603 . x$

Chernov, Yu. I. (1965): Faunal features of spotted tundras. - Zoological Zhurnal 44: 507-512. [In Russian]

Folmer, O., Black, M., Hoen, W., Lutz, R. \& Vrijenhoek, R. (1994): DNA primers for amplification of mitochondrial cytochrome c oxidase subunit I from diverse metazoan invertebrates. - Molecular Marine Biology and Biotechnology 3: 294-299.

Fridolin, V. Yu. (1936): Animal and plant communities of the Khibiny mountains I. - Proceedings of the Kola Station AS USSR 3: 19-295. [In Russian]

Hansen, P. L., Holmstrup, M., Bayley, M. \& Simonsen, V. (2006): Low genetic variation for Dendrobaena octaedra from Greenland compared to populations from Europe and North America: Refuge or selection? - Pedobiologia 50: 225-234. https://doi.org/10 .1016/j.pedobi.2005.12.001

Hewitt, G. (2000): The genetic legacy of the Quaternary ice ages. - Nature 405: 907-913. https://doi.org/10.1038/35016000

James, S. W. (2011): Earthworms. Pp. 177-183. In: Simberloff, D. \& Rejmánek, M. (eds): Encyclopedia of biological invasions. University of California Press, Berkeley.

Haraldsen, T. K. \& Engelstad, F. (1998): Influence of earthworms on soil properties and crop production in Norway. - Centre for Soil and Environmental Research, Oslo, 12 pp.

Konakova, T. N., Kolesnikova, A. A., Taskaeva, A. A. \& Nakul, G. L. (2017): Diversity of soil invertebrates in the valley of the Chernaya river (Bolshezemelskaya tundra, Nenetz Autonomous Okrug). - Eurasian Entomological Journal 16: 88-98. [In Russian]

Mangerud, J., Gosse J., Matiouchrov, A. \& Dolvik, T. (2008): Glaciers in the Polar Urals, Russia, were not much larger during the Last Global Glacial Maximum than today. Quaternary Science Reviews 27: 1047-1057. https://doi.org/10.1016/j.quascirev.2008.01 .015

Martinsson, S. \& Erséus, C. (2017): Cryptic speciation and limited hybridization within Lumbricus earthworms (Clitellata: Lumbricidae). - Molecular Phylogenetics and Evolution 106: 18-27. https://doi.org/10.1016/j.ympev.2016.09.011

Martinsson, S., Rhodén, C. \& Erséus, C. (2017): Barcoding gap, but no support for cryptic speciation in the earthworm Aporrectodea longa (Clitellata: Lumbricidae) - Mitochondrial DNA 28: 147-155. https://doi.org/10.3109/19401736.2015.1115487

Meshcheryakova, E. N. \& Berman, D. I. (2014): The coldhardiness and geographic distribution of earthworms (Oligochaeta, Lumbricidae, Moniligastridae). - Zoological Zhurnal 93: 53-64. [In Russian]

Michaelsen, W. (1903): Die geographische Verbreitung der Oligochaeten. - Friedländer \& Sohn, Berlin, 183 pp. https://doi.org/10.5962/bhl.title.11667

PERel, T. S. (1979): Range and regularities in the distribution of earthworms of the USSR fauna. Nauka, Moscow, 272 pp. [In Russian]

Provan, J. \& Bennett, K. D. (2008): Phylogeographic insights into cryptic glacial refugia. Trends in Ecology and Evolution 23: 564-571. https://doi.org/10.1016/j.tree.2008.06.010 
Reynolds, J. W. (1995): The distribution of earthworms (Annelida, Oligochaeta) in North America. Pp 133-153. In: Mishra, P. C., Behera, N., Senapati, B. K. \& Guru, B. C. (eds): Advances in Ecology and Environmental Sciences. - Ashish Publishing House, New Delhi.

Reynolds, J. W. (2017): A summary of the status of earthworms (Annelida: Oligochaeta) in ecoregions of the United States. - Megadrilogica 23: 161-200.

Rybalov, L. B. \& Kamayev, I. O. (2012): Comparative analysis and long-term dynamics of soil macrofauna in forest-tundra ecotone of the Khibiny mountains. - Russian Entomological Journal 21: 179-183.

Sheknovtsov, S. V., Golovanova, E. V. \& Peltek, S. E. (2013): Cryptic diversity within the Nordenskiold's earthworm, Eisenia nordenskioldi subsp. nordenskioldi (Lumbricidae, Annelida). - European Journal of Soil Biology 58: 13-18. https://doi.org/10.1016 /j.ejsobi.2013.05.004

Shekhovtsov, S. V., Golovanova, E. V. \& Peltek, S. E. (2014): Invasive lumbricid earthworms of Kamchatka (Oligochaeta). - Zoological Studies 53: 52. https://doi.org/10.1186 /s40555-014-0052-0

Shekhovtsov, S. V., Berman, D. I. \& Peltek, S. E. (2015): Phylogeography of the earthworm Eisenia nordenskioldi nordenskioldi (Lumbricidae, Oligochaeta) in Northeastern Eurasia. - Doklady Biological Sciences 461: 1-4. https://doi.org/10.7868/S0869565215070282

Shekhovtsov, S. V., Berman, D. I., Bazarova, N. E., Bulakhova, N. A., Porco, D. \& Peltek S. E. (2016a): Cryptic genetic lineages in Eisenia nordenskioldi pallida (Oligochaeta, Lumbricidae). - European Journal of Soil Biology 75: 151-156. https://doi.org/10.1016 /j.ejsobi.2016.06.004

Shekhovtsov, S. V., Golovanova, E. V. \& Peltek, S. E. (2016b): Mitochondrial DNA variation in Eisenia n. nordenskioldi (Lumbricidae) in Europe and Southern Urals. - Mitochondrial DNA 27: 4643-4645. https://doi.org/10.3109/19401736.2015.1101594

Sheknovtsov, S. V., Golovanova, E. V. \& Peltek, S. E. (2016c): Different dispersal histories of lineages of the earthworm Aporrectodea caliginosa (Lumbricidae, Annelida) in the Palearctic. - Biological Invasions 18: 751-761. https://doi.org/10.1007/s10530-015-1045-6

Shekhovtsov, S. V., Berman, D. I., Bulakhova, N. A., Vinokurov, N. N. \& Peltek, S. E. (2018a): Phylogeography of Eisenia nordenskioldi nordenskioldi (Lumbricidae, Oligochaeta) from the north of Asia. - Polar Biology 41: 237-247. https://doi.org/10.1007 /s00300-017-2184-2

Shekhovtsov, S. V., Blakemore, R. J., Sundukov, Yu. N., Gongalsky, K. B. \& Peltek, S. E. (2018b): Earthworm fauna (Oligochaeta, Megadrili) of the Southern Kuril Islands and its origin. - Animal Biodiversity and Conservation 41: 9-17.

StebAev, I. V. (1959): Soil invertebrates of Salekhard tundra and their response to agriculture. - Zoological Zhurnal 33: 1559-1572. [In Russian]

Sтöp-Bowitz, C. (1969): A contribution to our knowledge of the systematics and zoogeography of Norwegian earthworms (Annelida, Oligochaeta: Lumbricidae). - Nytt Magasin for Zoologi 17: 169-280.

Striganova, B. R. \& Porjadina, N. M. (2005): Soil animal population in boreal forests of WestSiberian plain. - KMK Scientific Press Ltd., Moscow, 2332 pp. [In Russian]

Svendsen, J. I., Alexanderson, H., Astakhov, V. I., Demidov, I., Dowdeswell, J. A., Funder, S., Gataullin, V., Henriksen, M., Hjort, C., Houmark-Nielsen, M., Hubberten, H. W., Ingólfson, O., Jakobsson, M., KJÆer, K., Larsen, E., Lokrantz, H., LunkKa, J. P., Lys̊̊, A., Mangerud, J., Matiouchkov, A., Murray, A., Möller, P., Niessen, F., Nikolskaya, O., Polyak, P., Saarnisto, M., Siegert, C., Siegert, M., Spielhagen, R. \& 
STEIN, R. (2004): Late Quaternary ice sheet history of Northern Eurasia. - Quaternary Science Reviews 23: 1229-1271. https://doi.org/10.1016/j.quascirev.2003.12.008.

Terhivuo, J. (1998): The Finnish Lumbricidae (Oligochaeta) fauna and its formation - Annales Zoologici Fennici 3: 229-247.

Tiкномirov, B. A. (1937): On earthworm environmental in tundra soils - Priroda 5: 52-58. [In Russian]

Tiunov, A. V., Hale, C. M., Holdsworth, H. M. \& Vsevolodova-Perel, T. S. (2006): Invasion patterns of Lumbricidae into the previously earthworm-free areas of northeastern Europe and the western Great Lakes region of North America. - Biological Invasions 8: 1223-1234. https://doi.org/10.1007/s10530-006-9018-4.

Vsevolodova-Perel, T. S. (1997): The earthworms of the fauna of Russia. - Nauka, Moscow, 102 pp. [In Russian]

Zenkova, I. V. \& RApoport, I. B. (2011): Species richness and high altitude distribution of earthworms in the Khibiny Massive (Murmansk Region) (Oligochaeta). Pp. 141-151. In: KaspareK, M. (ed.): Advances in earthworm taxonomy VI (Annelida: Oligochaeta). Proceedings of the 6th International Oligochaete Taxonomy Meeting, 6th IOTM, Heidelberg. https://doi.org/10.13140/2.1.3734.7841

Received June 17, 2018, accepted August 1, 2018, published October 12, 2018 